\title{
PENGEMBANGAN LKS KEMAMPUAN PEMECAHAN MASALAH MATEMATIS SISWA KELAS VIII BERBASIS INKUIRI TERBIMBING BERBANTU MEDIA GRAFIS
}

\author{
Dewi Sarina Putri ${ }^{1}$, Selvi Riwayati ${ }^{2}$ \\ Program Studi Pendidikan Matematika Universitas Muhammadiyah Bengkulu ${ }^{1,2}$ \\ riwayatiselvi@gmail.com²
}

\begin{abstract}
ABSTRAK
Penelitian ini bertujuan untuk menghasilkan LKS yang valid dan praktis berbasis Inkuiri Terbimbing berbantu media grafis. Metode yang digunakan adalah metode penelitian pengembangan (research and development) dengan model 4D (four D) yaitu tahap pendefinisian (Define), tahap perancangan (Design), tahap pengembangan (Develop), dan tahap pendesiminasian (Disseminate). Penelitian dilakukan pada siswa kelas VIII SMPN 03 Kaur pada semester genap 2019/2020. Proses pengembangan LKS melalui 4 kali proses uji para ahli sampai dinilai memenuhi kriteria valid. Selanjutnya diujicoba terbatas kepada 6 siswa dan diperoleh kriteria praktis. Hasilnya diperoleh LKS yang valid dan praktis berbasis inkuiri terbimbing berbantu media grafis untuk kemampuan pemecahan masalah matematis siswa pada materi Prisma dan Limas kelas VIII SMP.
\end{abstract}

Kata kunci : LKS, pemecahan masalah, inkuiri terbimbing

\begin{abstract}
The aim of this study is to create valid and practical worksheets based on guided inquiry and graphic media. The research and development method is applied, using the $4 \mathrm{D}$ (four $\mathrm{D}$ ) model, which includes the defining stage (Define), the design stage (Design), the development stage (Develop), and the dissemination stage (Disseminate). The study was carried out on class VIII students at SMPN 03 Kaur during the even semester of 2019/2020. The procedure of producing worksheets and testing them four times until they are determined to fit the valid criteria. Furthermore, it was tested on a small group of six pupils, and practical criteria were achieved. The findings generated valid and practical worksheets for students' mathematical problem-solving abilities in the Prism and Pyramide material for class VIII SMP based on guided inquiry assisted by graphic media.
\end{abstract}

Keywords : students worksheets, problem solving, guided inquiry

\section{PENDAHULUAN}

Matematika merupakan salah satu mata pelajaran yang wajib pada jenjang pendidikan menengah pertama. Pada tingkat Sekolah Menengah Pertama (SMP) mata pelajaran matematika memiliki tujuan yang penting. Tujuan tersebut dimuat dalam Peraturan Menteri Pendidikan Nasional Republik Indonesia No. 64 Tahun 2013 tentang standar isi untuk tingkat Satuan Pendidikan dasar dan menengah dalam 
peraturan tersebut, dituliskan mata pelajaran matematika bertujuan agar siswa memiliki kompetensi yaitu diantaranya menunjukkan sikap logis, kritis, analitis, kreatif, cermat, teliti, bertanggung jawab, responsif dan tidak mudah menyerah dalam memecahkan masalah (Kemendikbud, 2013). Kemampuan pemecahan masalah merupakan kemampuan yang harus dimiliki siswa dalam menyelesaikan suatu masalah yang dihadapinya. Effendi (2012) menyatakan kemampuan pemecahan masalah harus dimiliki siswa untuk melatih agar siswa terbiasa menghadapi berbagai permasalahan, baik masalah dalam matematika, masalah dalam bidang studi lain ataupun masalah dalam kehidupan sehari-hari yang kompleks. Sehingga berdasarkan pendapat tersebut sangat jelas jika siswa harus memiliki kemampuan pemecahan masalah untuk dapat menyelesaikan permasalahan matematika.

Berdasarkan hasil pengamatan dan pengalaman magang III diketahui bahwa LKS yang digunakan berasal dari penerbit. Dimana LKS tersebut merupakan kumpulan materi-materi dan soal-soal yang disajikan untuk kemampuan pemecahan masalah matematis siswa belum efektif atau terlihat. Sehingga para guru diharapkan lebih kreatif dan inovatif dalam menciptakan pembelajaran yang dapat menjadikan siswa sebagai subjek belajar yang aktif, guru harus mampu mengembangkan bahan ajar yang sesuai dengan kebutuhan siswa sehingga optimalisasi pembelajaran di kelas dapat dicapai.

Daryanto dan Dwicahyo (2014) yang mengemukakan bahwa guru harus memiliki atau menggunakan bahan ajar yang sesuai dengan kurikulum, karakteristik, dan tuntutan pemecahan masalah belajar. Sehingga kegiatan pembelajaran menjadi lebih menarik dan memberikan kesempatan pada siswa untuk menggali kemampuan yang dimilikinya. Sehingga perlu dikembangkan bahan ajar salah satunya berupa Lembar Kerja Siswa (LKS) yang memuat penemuan-penemuan masalah secara sistematis.

Trianto (2007:73) mendefinisikan bahwa Lembar Kerja Siswa merupakan panduan siswa yang digunakan untuk melakukan kegiatan penyelidikan dan pemecahan masalah. Sedangkan menurut Majid (2012) LKS yakni berupa lembaranlembaran tugas yang harus dikerjakan oleh siswa, sehingga LKS merupakan lembaran-lembaran yang harus dikerjakan siswa yang berisi masalah-masalah yang harus dipecahkan. Trianto (2009: 222) mengemukakan lembar kerja siswa berfungsi sebagai panduan untuk latihan pengembangan aspek kognitif maupun semua aspek pembelajaran dalam bentuk panduan percobaan atau demonstrasi.

Untuk menerapkan LKS dalam pembelajaran, dibutuhkan model pembelajaran yang sesuai dengan kemampuan siswa. Salah satunya model pembelajaran yang menggunakan penemuan-penemuan baru dalam pemecahan masalah yaitu model Inkuiri terbimbing berbantu media grafis.

Inkuiri adalah suatu penyelidikan yang melibatkan siswa secara langsung dalam proses pembelajaran, siswa juga dilatih untuk meneliti dan memecahkan suatu permasalahan atau pertanyaan dengan fakta-fakta yang ada. Menurut Damayanti (2013) Inkuiri terbimbing (Guided inquiry) yaitu suatu inkuiri yang dalam pelaksanaannya guru menyediakan bimbingan atau petunjuk cukup luas kepada siswa. Guru membuat rencana pembelajaran atau langkah-langkah percobaan dan siswa melakukan percobaan atau penyelidikan untuk menemukan konsep-konsep yang telah ditetapkan oleh guru. 
Selain menerapkan model pembelajaran inkuiri terbimbing, penggunaan media grafis dapat membantu siswa dalam memahami masalah yang diajarkan oleh guru. Ibrahim, dkk (Putra dkk, 2014) mengemukakan media grafis adalah material media tanpa proyeksi dua dimensi, pada umumnya berupa gambar atau tulisan. Pendapat ini menyatakan bahwa media grafis biasanya berupa gambar atau tulisan yang mudah dipahami siswa. Sedangkan menurut Sudjana (2008:68) media grafis adalah media yang mengkombinasikan fakta dan gagasan secara jelas dan kuat melalui kombinasi pengungkapan kata-kata dengan gambar-gambar. Sehingga media grafis adalah semua media visual yang menyatakan fakta, gagasan atau kejadian melalui kombinasi kata, kalimat, angka dan gambar ataupun simbol-simbol visual lain.

Oleh karena itu, untuk meningkatkan kemampuan pemecahan masalah matematis siswa dapat dilakukan dengan mengembangkan bahan ajar berupa LKS dengan model inkuiri terbimbing berbantu media grafis. Dengan demikian, tujuan penelitian ini adalah untuk menghasilkan LKS yang valid dan praktis berbasis Inkuiri Terbimbing berbantu media grafis.

\section{METODE}

Jenis penelitian yang digunakan adalah penelitian dan pengembangan (research and development). Research and development adalah metode penelitian yang digunakan untuk menghasilkan produk tertentu dan menguji keefektifan produk tersebut (Sugiyono, 2008:407). Produk yang dihasilkan dalam penelitian ini adalah LKS matematika yang valid dan praktis berbasis inkuiri terbimbing berbantu media grafis untuk memfasilitasi kemampuan pemecahan masalah matematis siswa SMP/MTS kelas VIII semester 2 pada materi prisma dan limas. Penelitian dilakukan pada siswa kelas VIII SMPN 03 Kaur pada semester genap 2019/2020.

Model pengembangan yang dijadikan sebagai acuan dalam penelitian ini adalah model Thiagarajan. Model Thiagarajan ini dikenal dengan Model 4-D yang dilakukan melalui 4 tahap, yaitu pendefinisian (define), perancangan (design), pengembangan (develop), dan penyebaran (disseminate) (Kurniawan dan Dewi 2017). Tetapi dalam penelitian ini hanya dilakukan sampai tahap develop (pengembangan) sedangkan tahap disseminate (penyebaran) belum dilakukan. Produk akan divalidasi oleh pakar untuk analisis validitas terhadap LKS yang akan dikembangkan, kemudian akan diujicoba kepada siswa, subjek ujicoba terbatas adalah siswa kelas VIII sebanyak 6 orang, tetapi penelitian ini hanya sampai tahap ujicoba terbatas saja karena pada masa pandemi covid-19 ini tidak memungkinkan untuk ujicoba selanjutnya.

Jenis data pada penelitian ini adalah data kualitatif dan data kuantitatif. Data kualitatif didapat dari hasil analisis data yang bersifat deskriptif kualitatif berupa komentar dan saran dosen yang dijadikan acuan untuk merevisi produk sampai mendapatkan hasil yang valid. Data kuantitatif didapat dari hasil analisis lembar kepraktisan yang diisi siswa.

\section{HASIL DAN PEMBAHASAN}

Penelitian pengembangan ini menggunakan model pengembangan Thiagarajan atau model 4-D, dimana dalam pengembangan LKS ini model 4-D ini dimodifikasi menjadi 3 tahap yaitu tahap pendefinisian (define), tahap perancangan (design), dan tahap pengembangan (development). Penelitian ini menghasilkan LKS yang valid 
dan praktis berbasis inkuiri terbimbing berbantu media grafis untuk meningkatkan kemampuan pemecahan masalah matematis siswa pada materi prisma dan limas.

Pada tahap pendefinisian yang dimulai dari analisis awal-akhir didapatkan bahwa guru bidang studi matematika sudah menerapkan kurikulum 2013, akan tetapi belum adanya pelaksanaan pengembangan perangkat pembelajaran yang mengacu pada K13. Dalam proses pembelajaran guru tidak menggunakan LKS, terlebih lagi LKS yang dapat mengembangkan kemampuan pemecahan masalah matematis siswa. Berdasarkan analisis kurikulum 2013 maka penelitian ini memilih materi prisma dan limas untuk LKS yang dikembangkan. Analisis siswa sangat penting dilakukan pada awal perencanaan. Analisis siswa dilakukan dengan cara mengamati karakteristik siswa yaitu kemampuan akademis dan perkembangan kognitif siswa. Analisis ini dilakukan dengan mempertimbangkan ciri, kemampuan, dan pengalaman siswa, baik sebagai kelompok maupun individu. Analisis siswa meliputi karakteristik kemampuan akademik, usia, dan motivasi terhadap mata pelajaran. Berdasarkan hasil analisis siswa, siswa kelas VIII SMPN 03 Kaur memiliki kemampuan tinggi, sedang, dan rendah. Masih ada siswa yang susah memahami materi yang diajarkan oleh gurunya, terutama saat memecahkan suatu masalah. Sehingga penelitian ini mengembangkan LKS berbasis inkuiri terbimbing berbantu media grafis untuk kemampuan pemecahan masalah matematis agar dapat membantu siswa lebih mudah memahami materi yang diajarkan serta dapat menggali lebih dalam kemampuan yang dimiliki siswa.

Pada tahap analisis konsep, bertujuan untuk mengidentifikasi dan menyusun secara sistematis konsep-konsep yang relevan berdasarkan analisis awal. Berdasarkan K-13 untuk kelas VIII SMP semester genap, maka analisis konsep pada pokok bahasan Pisma dan Limas disajikan sebagai berikut:

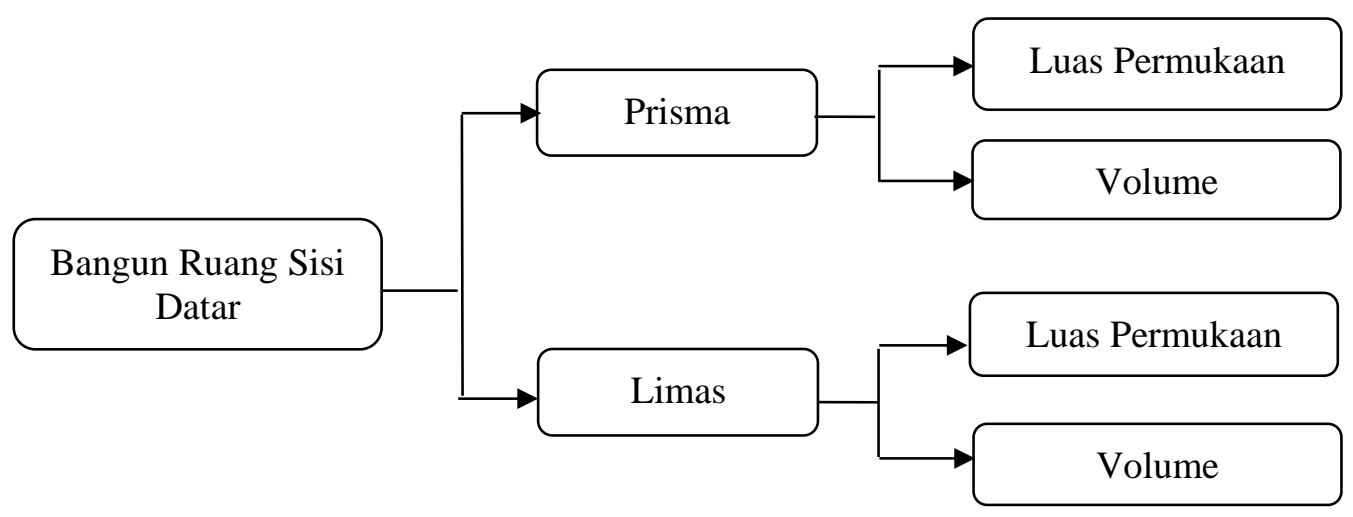

Gambar 1. Bagan peta konsep pokok bahasan bangun ruang sisi datar

Berdasarkan analisis tugas, maka keterampilan yang harus dimiliki siswa adalah sebagai berikut:

a) Siswa dapat memahami masalah yang berkaitan dengan luas permukaan dan volume prisma dan limas.

b) Siswa dapat merencanakan strategi dalam menyelesaikan luas permukaan dan volume prisma dan limas.

c) Siswa dapat melaksanakan rencana untuk menyelesaikan permasalahan yang berkaitan dengan luas permukaan dan volume prisma dan limas. 
d) Siswa dapat menyimpulkan hasil dari permasalahan yang berkaitan dengan luas permukaan dan volume prisma dan limas.

Perumusan tujuan pembelajaran dilakukan dengan menjabarkan indikator pencapaian hasil belajar ke dalam indikator yang lebih spesifik berdasarkan analisis konsep dan analisis tugas. Indikator pencapaian hasil belajar yang lebih spesifik tersebut diuraikan sebagai berikut:

1) Siswa dapat memahami masalah yang berkaitan dengan luas permukaan dan volume prisma dan limas.

2) Siswa dapat merencanakan strategi dalam menyelesaikan luas permukaan dan volume prisma dan limas.

3) Siswa dapat melaksanakan rencana untuk menyelesaikan permasalahan yang berkaitan dengan luas permukaan dan volume prisma dan limas.

4) Siswa dapat menyimpulkan hasil dari permasalahan yang berkaitan dengan luas permukaan dan volume prisma dan limas.

Tahap perancangan (design) bertujuan untuk menghasilkan prototype I. pada tahap perancangan ini LKS dirancang berdasarkan dengan analisis pada tahap pendefinisian yakni analisis awal, analisis konsep, analisis siswa, analisis tugas, dan analisis perumusan tujuan pembelajaran. LKS ini disesuaikan dengan model inkuiri terbimbing yang berorientasi pada kemampuan pemecahan masalah matematis.

Pada tahap pengembangan (development) yang dilakukan adalah validasi dan uji terbatas. Proses validasi untuk memperoleh validitas LKS dan uji terbatas untuk memperoleh kepraktisan LKS.

1. Validitas

Prototype I yang dihasilkan dari tahap perancangan divalidasi oleh 2 orang validator. Hasil validasi dari prototype I menunjukkan bahwa LKS masih belum valid. Masih terdapat banyak kesalahan sehingga diperlukan perbaikan atau revisi. Kemudian hasil revisi tersebut menghasilkan prototype II dan divalidasi kembali oleh para validator. Hasil validasi dari prototype II menunjukkan bahwa LKS masih belum valid. Masih terdapat beberapa kesalahan sehingga diperlukan perbaikan atau revisi. Kemudian hasil revisi tersebut menghasilkan prototype III dan divalidasi kembali oleh para validator. Hasil validasi dari prototype III menunjukkan bahwa LKS masih belum valid. Masih terdapat sedikit kesalahan sehingga diperlukan perbaikan atau revisi. Kemudian hasil revisi tersebut menghasilkan prototype IV dan divalidasi kembali oleh para validator. Hasil validasi menunjukkan bahwa LKS prototype IV sudah valid menurut para validator dari segi bahasa, isi, dan konstruk. Sehingga berdasarkan komentar dan saran dari para ahli bahwa LKS ini telah memenuhi kriteria kevalidan. Kriteria valid yang diperoleh menunjukkan bahwa LKS telah sesuai dengan validasi ahli dan layak digunakan. 

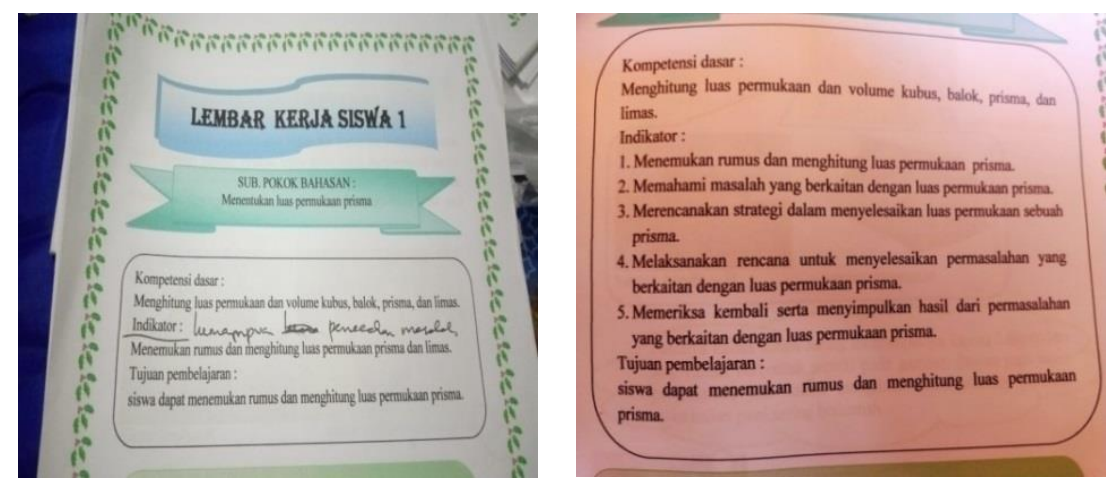

Gambar 2. LKS sebelum dan sesudah validasi

Saran dari validator yaitu sesuaikan indikator pembelajaran dengan indikator kemampuan pemecahan masalah matematis, agar saat siswa mengerjakan LKS mereka memecahkan masalah yang diberikan serta inkuiri terbimbingnya belum terlihat.
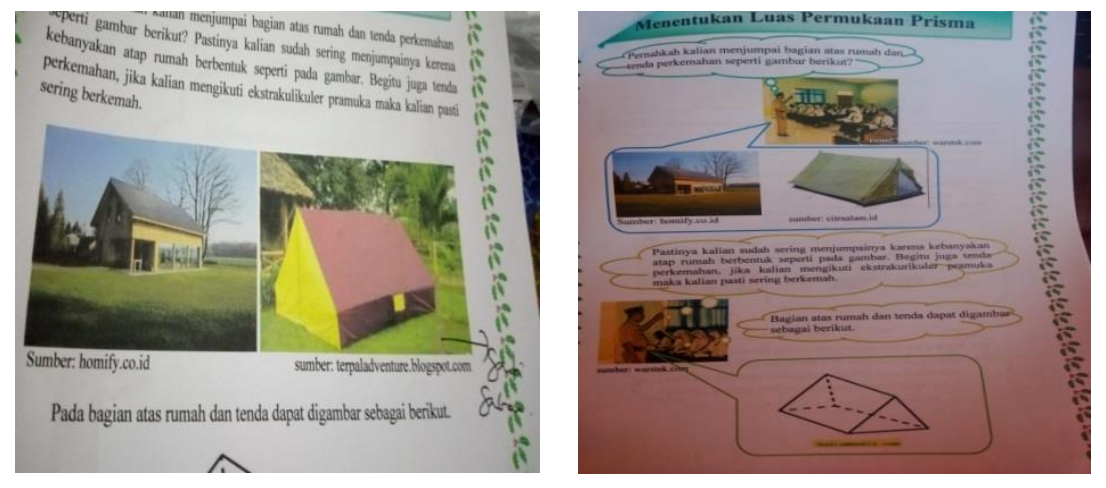

Gambar 3. LKS sebelum dan sesudah validasi

Saran dari validator yaitu perbaiki cara penulisan atau tata letak spasi, ganti atau perkecil gambar agar meminimalisir kertas yang digunakan dan tambahkan sumber dari gambar.
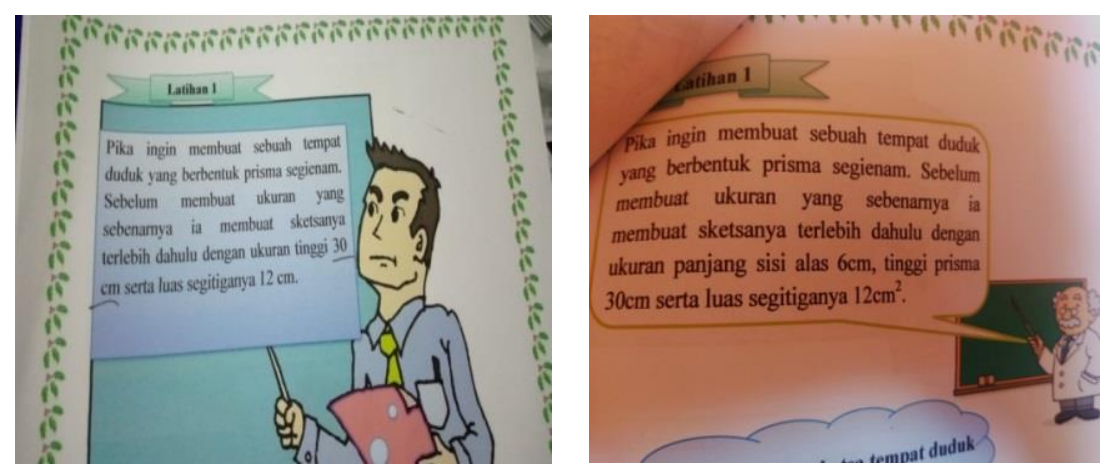

Gambar 4. LKS sebelum dan sesudah validasi 
Saran dari validator yaitu perbaiki dan perhatikan tentang penulisan yang benar pada soal-soalnya, ada beberapa soal yang perlu diganti konteks ceritanya serta tambahkan beberapa foto yang sesuai dengan soal agar siswa bisa lebih memahami masalah pada soal yang diberikan.

Berdasarkan uraian hasil revisi validasi beberapa prototype, LKS sudah dinyatakan baik dan valid. Karena bagian LKS yang harus diperbaiki sudah diperbaiki, maka tidak terdapat bagian yang harus direvisi lagi, sehingga LKS bisa diujicobakan.

Dari hasil validasi tersebut menghasilkan LKS matematika yang valid sesuai dengan model inkuiri terbimbing berbantu media grafis pada materi prisma dan limas untuk kemampuan pemecahan masalah matematis siswa SMP. Setelah itu LKS akan diujicobakan untuk melihat kepraktisan oleh pengguna berdasarkan respon siswa.

\section{Kepraktisan}

LKS yang telah direvisi dinamakan prototype IV yang akan digunakan untuk ujicoba terbatas terhadap 6 orang siswa. Pada ujicoba terbatas ini didapatkan kepraktisan terhadap penggunaan LKS yang dikembangkan. Selanjutnya karena pada masa pandemi covid-19 ini sekolah di seluruh Indonesia belajar online dari rumah tidak terkecuali SMPN 03 Kaur, jadi LKS ini hanya sampai pada tahap uji terbatas, kalau mau dilanjutkan ke tahap ujicoba luas tidak memungkinkan. Berdasarkan analisis kepraktisan diperoleh hasil bahwa LKS yang telah diujicoba terbatas tersebut tergolong praktis dan tidak perlu lagi mengalami revisi, sehingga LKS layak untuk digunakan untuk ujicoba lanjutan.

Tabel 1. Data kepraktisan penggunaan LKS

\begin{tabular}{clcc}
\hline No. & \multicolumn{1}{c}{ Aspek yang dinilai } & $\bar{x}$ & $\begin{array}{c}\text { Kriteria } \\
\text { kepraktisan }\end{array}$ \\
\hline 1. & $\begin{array}{l}\text { Tulisan pada Lembar Kerja Siswa (LKS) dapat } \\
\text { dibaca dengan mudah }\end{array}$ & 3,83 & Praktis \\
$\begin{array}{l}\text { Penggunaan Bahasa Indonesia dalam Lembar } \\
\text { 2. } \begin{array}{l}\text { Kerja Siswa (LKS) sudah sesuai dengan kaidah } \\
\text { penulisan Bahasa Indonesia }\end{array}\end{array}$ & 3,7 & Praktis \\
3egiatan pada lembar kerja siswa(LKS) dilakukan \\
$\begin{array}{l}\text { secara runtut dan melatih keterampilan siswa } \\
\text { Penggunaan gambar dan ilustrasi dalam Lembar }\end{array}$ & 3,62 & Praktis \\
4erja Siswa (LKS) menunjukkan makna dari & 3,62 & Praktis \\
$\begin{array}{l}\text { masalah kontekstual yang disajikan } \\
\text { Penggunaan Lembar Kerja Siswa (LKS) dapat } \\
\text { memotivasi dalam belajar }\end{array}$ & 3,83 & Praktis \\
\hline Jumlah & 18,6 & Praktis \\
\hline
\end{tabular}

Berdasarkan tabel 1 dari semua aspek yang dinilai diperoleh rata-rata penilaian kepraktisan sebesar 3,72. Berdasarkan kriteria kepraktisan, dapat disimpulkan bahwa penggunaan LKS oleh siswa tergolong praktis yakni berada pada rentang skor $3,4<\bar{P}_{L K S} \leq 4,2$.

Berdasarkan uraian di atas dapat dikatakan bahwa LKS yang dikembangkan sudah tergolong valid dan praktis, serta dapat digunakan pada ujicoba lanjutan 
pembelajaran matematika untuk kemampuan pemecahan masalah matematis. Hal ini sejalan dengan penelitian Khasanah (2016) bahwa LKS berbasis inkuiri terbimbing berbantuan media grafis merupakan bahan ajar yang dapat meningkatkan kemampuan pemecahan masalah matematis dan layak untuk digunakan dalam kegiatan pembelajaran matematika. Selain itu, hasil penelitian dari Putri (2019) mengatakan bahwa LKS dengan model problem based learning dapat membantu dalam belajar dan memudahkan serta memotivasi siswa untuk memahami materi yang diajarkan. Hal ini menunjukkan bahwa LKS dapat mempengaruhi hasil belajar siswa, penggunaan LKS juga membantu siswa untuk mencapai ketuntasan dalam mempelajari materi. Sehingga dapat disimpulkan bahwa pengembangan LKS pada penelitian ini valid berdasarkan uji validasi yang telah dilakukan oleh 2 orang validator dan praktis berdasarkan penilaian kepraktisan dengan skor 3,72. Maka, LKS berbasis inkuiri terbimbing berbantu media grafis ini telah layak digunakan untuk meningkatkan kemampuan pemecahan masalah matematis siswa.

3. Kendala dan kekurangan dalam penelitian

Penelitian pengembangan ini tidak terlepas dari kendala dan kekurangan dalam pelaksanaannya, adapun beberapa kendala dan kekurangan dalam pelaksanaan penelitian ini:

a) LKS berbasis inkuiri terbimbing berbantu media grafis untuk kemampuan pemecahan masalah matematis yang dikembangkan hanya sebatas materi prisma dan limas.

b) Terbatasnya ujicoba yang dilakukan karena pandemi covid-19.

\section{SIMPULAN DAN SARAN}

Proses pengembangan LKS berbasis inkuiri terbimbing berbantu media grafis untuk kemampuan pemecahan masalah matematis pada materi prisma dan limas ini melalui beberapa tahapan sesuai dengan model pengembangan 4-D. Dari proses pengembangan yang dilakukan, LKS melalui 4 kali proses uji para ahli sampai dinilai memenuhi kriteria valid. LKS yang sudah valid tersebut selanjutnya diujicobakan kepada 6 siswa. Hasil dari pengembangan LKS tersebut dinyatakan valid berdasarkan hasil analisis validator dan praktis berdasarkan ujicoba terbatas terhadap 6 siswa.

Disarankan kepada guru untuk menggunakan LKS berbasis inkuiri terbimbing berbantu media grafis materi luas permukaan dan volume prisma dan limas ini dalam pembelajaran matematika di kelas. Guru dapat juga memodifikasinya dan memperluasnya sesuai keperluan.

\section{DAFTAR PUSTAKA}

Damayanti, D. S. 2013. Pengembangan Lembar Kerja Siswa (LKS) dengan Pendekatan Inkuiri Terbimbing Untuk Mengoptimalkan Kemampuan Berpikir Kritis Peserta Didik Pada Materi Listrik Dinamis SMA Negeri 3 Purworejo Kelas X Tahun Pelajaran 2012/2013. RADIASI: Jurnal Berkala Pendidikan Fisika, Vol. 3(1) : 58-62.

Daryanto, D. dan Dwicahyo, A. 2014. Pembelajaran Tematik Terpadu Terintegrasi Kurikulum 2013. Yogyakarta: Gava Media. 
Effendi, L. A. 2012. Pembelajaran Matematika dengan Metode Penemuan Terbimbing Untuk Meningkatkan Kemampuan Representasi dan Pemecahan Masalah Matematis Siswa SMP. Jurnal Penelitian Pendidikan, Vol. 13(2) : 110.

Kemendikbud, R. I. 2013. Bahan Pelatihan Kurikulum 2013. Jakarta: Kemdikbud.

Khasanah, U. 2016. Pengembangan Lembar Kerja Siswa (LKS) Berbasis Inkuiri Terbimbing Berbantuan Media Grafis Pada Mata Pelajaran Matematika Kelas VIII MTs Al-Hikmah Bandar Lampung. Skripsi tidak diterbitkan. Lampung: UIN Raden Intan Lampung.

Kurniawan, D. dan Dewi, S. V. 2017. Pengembangan Perangkat Pembelajaran dengan Media Screencast-O-Matic Mata Kuliah Kalkulus 2 Menggunakan Model 4-D Thiagarajan. Jurnal Siliwangi Seri Pendidikan, Vol. 3(1) : 214-219.

Majid, A. 2012. Perencanaan Pembelajaran Mengembangkan Standar Kompetensi Guru. Bandung: PT. Remaja Rosdakarya.

Peraturan Menteri Pendidikan Nasional No. 64 Tahun 2013 Standar Isi Untuk Tingkat Satuan Pendidikan Dasar dan Menengah.

Putra, E. P., Garminah, N. N., dan Japa, I. G. N. 2014. Pengaruh Model Pembelajaran Inkuiri Terbimbing Berbantuan Media Grafis Terhadap Hasil Belajar Matematika Kelas IV SD di Gugus 4 Kecamatan Busungbiu. Journal Mimbar PGSD Undiksha, Vol. 2(1) : 1-10.

Putri, R.R. 2019. Pengembangan Lembar Kerja Siswa Matematika Untuk Kemampuan Pemecahan Masalah Matematis dengan Model Problem Based Learning Pada Pokok Bahasan Nilai Mutlak. Skripsi tidak diterbitkan. Bengkulu: Universitas Muhammadiyah Bengkulu.

Sudjana, N. 2008. Penilaian Hasil dan Proses Belajar Mengajar. Bandung: PT. Remaja Rosdakarya.

Sugiyono. 2008. Metode Penelitian Pendidikan (Pendekatan Kuantitatif, Kualitatif dan $R \& D$ ). Bandung: Alfabeta.

Trianto. 2007. Model Pembelajaran Terpadu dalam Teori dan Praktek. Surabaya: Prestasi Pustaka.

Trianto. 2009. Mendesain Model Pembelajaran Inovatif Progresif. Jakarta: Kencana. 